\title{
OPTIMIZING PRE LIMING PH FOR EFFICIENT JUICE CLARIFICATION PROCESS IN SRI LANKAN SUGAR FACTORIES
}

\author{
M.G.G Natasha Sewwandi \\ Pro0cessing Technology Division \\ Sugarcane Research Institute, Uda Walawe, SriLanka \\ Buddhika Sampath Kumara \\ Department of Engineering Technology \\ Sabaragamuwa University of Sri Lanka
}

\begin{abstract}
This study was conducted treating with Milk of Lime to reach different $\mathrm{pH}$ levels (T1- with Initial pH, T2, $\mathrm{T3}$ and $\mathrm{T} 4$ with $6.5,7.5$ and 8.5 of $\mathrm{pH}$ respectively) to determine the optimum pre-liming $\mathrm{pH}$ which could result in best cane juice clarification in Sri Lankan sugar industries. The experiment design used was RCBD with five replicates. ANOVA followed by Duncan's Multiple Range Test (DNMRT) were used to identify significant mean differences. Regression analyses were carried out to model the variation of turbidity, mud volume and $\mathrm{CaO}$ with change of juice $\mathrm{pH}$. Quadratic model $(\mathrm{R2}=99.2 \%$, $<0.001)$ best fitted to explain the effect of $\mathrm{pH}$ on turbidity of juice. Effect of $\mathrm{pH}$ on deposited mud volume and $\mathrm{CaO}$ were explained by cubic models with $\mathrm{R} 2=99.4 \%$ ( $<0.001)$ and $R 2=93.9 \%,(p<0.001)$ respectively.

Among tested treatments, $\mathrm{pH} 7.5$ is selected as the best for turbidity improvement of the clarified juice while $\mathrm{pH} 8.5$ is the second best. However pH $8.5(370 \mathrm{ml})$ was able to deposited significantly high mud volume than pH 7.5 (270 $\mathrm{ml}$ ). Further, the amount of residual $\mathrm{Ca} 2+$ ions in the clarified juice at $\mathbf{p H} 7.5(2715 \mathrm{ppm})$ is clearly lower than the amount of $\mathrm{Ca} 2+$ ions remaining in the clarified juice at pH 8.5 (2945 ppm). It is expected to obtain high turbidity and higher mud volume with low sugar inversion at optimum pH. Therefore the results suggest optimum pH range lie around $\mathrm{pH} 7.5$ to 8.5 . Conducting similar experiment by using mixed juice extracted from sugar factory mills with $\mathrm{pH}$ range around 7.0 to 8.4 at 0.2 increments is suggested to validate the optimum $\mathrm{pH}$.
\end{abstract}

Keywords - Defecation, Degradation, inversion, Sugar cane, pH, reducing sugar, Turbidity

\section{INTRODUCTION}

Clarification is the one of main important process in the sugar manufacturing process. Because clarification affects the juice filterability, sucrose crystallization and the quality and yield of

\author{
Sandya Ariyawansha \\ Economics Biometry \& IT Division \\ Sugarcane Research Institute, Uda Walawe, SriLanka \\ Aloka Maralanda \\ Processing Technology Division \\ Sugarcane Research Institute, Uda Walawe, SriLanka
}

raw sugar produced. The main purpose of sugar cane juice clarification is to produce clarified juice $(\mathrm{CJ})$ with the lowest concentration of insoluble and soluble impurities. Screening of juice eradicates only the coarse particles since flocculation is necessary to remove the fine and colloidal particles. Therefore flocculation technique is used in clarification process to provide clarified Juice [1].

The conventional method for juice clarification in Sri Lankan sugar industry is that defecation. During the defecation process, Mixed Juice is heated from $\sim 35-55^{\circ} \mathrm{C}$ to $\sim 760 \mathrm{C}$ and treated with Lime as milk of lime or lime saccharate to raise the $\mathrm{pH}$ from $\sim 5.2$ to $7.5-7.8$ [2]. Lime is added to react with inorganic phosphate present in the cane juice to form calcium phosphate floc. These macro-flocs have a higher density relative to juice and settle by gravity. The settled flocculated mud impurities are extracted from the clarifier to recover trapped sucrose. In order to recover the trapped sucrose, rotating vacuum filters are used. The filtrate is recirculated and combined with Mixed Juice [3].

In sugarcane, the natural phosphates are occurring in two forms; inorganic (soluble) and organic (insoluble) phosphates. Only the soluble phosphate will react with the lime to form a Calcium Phosphate precipitate. Since presence of phosphates in cane juice is essential for good clarification process, phosphate should be added externally before liming if natural $\mathrm{P}_{2} \mathrm{O}_{5}$ content (about $200 \mathrm{mg} / \mathrm{l}$ ) low in mixed juice [4].

Apart from that during the defecation process, a wide range of chemical and physical reactions takes place in the juice. The main chemical reactions include: Precipitation of amorphous calcium phosphate, proteins denaturation (and other organics, such as pectins, gums and waxes), inversion of sucrose due to the combined action of $\mathrm{pH}$ and temperature, degradation of reducing sugars to organic acids due to high $\mathrm{pH}$ and temperature, precipitation of organic and inorganic acid salts, hydrolysis of starch by the natural amylase in the juice and formation of colour bodies due to the polymerization 


\section{International Journal of Engineering Applied Sciences and Technology, 2021 \\ Vol. 6, Issue 1, ISSN No. 2455-2143, Pages 14-20 \\ Published Online May 2021 in IJEAST (http://www.ijeast.com)}

(either enzymatically or thermally) of flavonoids and phenolic compounds [5].

The poor quality of clarified juice contributes to scaling of the evaporators and pans, and also increases the probability of sucrose loss to molasses. Clarification also have an impact on crystal morphology, color, crystal content, and polysaccharide and ash contents of raw sugar. And also Juice clarification has a great impact on factory evaporators' heat transfer coefficients particularly if scaling occurs from the excessive addition of lime [6]. Therefore it is important to optimize main operating parameters such as $\mathrm{pH}$, temperature, type \& dosage of flocculent, etc. to minimize impact to the subsequent process and overcome existing problems associated with the juice clarification process in local sugar factories. Among them $\mathrm{pH}$ is the one of important parameter in clarification, since $\mathrm{pH}$ of about 7 is necessary to neutralize the charge on the fine suspended particle in the juice to facilitate coagulation and settling. In addition, $\mathrm{pH}$ is important to the rate at which certain reaction occurs especially the precipitation of calcium phosphate. The juice $\mathrm{pH}$ was shown to have suggestions on the inversion losses, loss of sugar, color formation, sugar quality, and scaling in subsequent processes. Therefore this research is carried out some recent laboratory work to quantify the effects of different $\mathrm{pH}$ levels to clarified juice quality and floc settling behavior reflected by deposited mud volume.

\section{MATERIALS AND METHODS}

\section{A. Preparation of Milk of Lime -}

Fig. 1.For juice clarification in sugar factories milk of lime is prepared at a concentration of 6 to $10{ }^{\circ} \mathrm{Be}$ (degree Baume). Therefore, milk of Lime solution was prepared with $10{ }^{\circ} \mathrm{Be}$ during this study. For MOL, powdered, hydrate lime $(\mathrm{Ca}(\mathrm{OH}) 2)(37.6 \mathrm{~g})$ was added to preheated $\left(60^{\circ} \mathrm{C}\right)$ deionized water $(400 \mathrm{ml})$ and mixed well.

\section{B. Treatment structure -}

The variety SL 96 128, which is the major commercial variety grown in Sri Lanka was used to obtain the juice for the preceding analysis. 5L of juice was extracted from the sugar mill (Mixed juice, MJ) and initial readings of Brix, Pol, Purity, reducing sugar, turbidity, TSS and TDS of mixed juice were taken. After that four samples were prepared by measuring $1 \mathrm{~L}$ of mixed juice in to conical flask separately. Then each of samples were treated with prepared Milk of Lime to reach different $\mathrm{pH}$ levels according to following table and required quantity of MOL volume was recorded for each sample.

Table - 1 Juice samples treating with different $\mathrm{pH}$ liming for clarification

\begin{tabular}{cc}
\hline Treatment No. (Sample) & Limed pH \\
\hline T1 (Sample 1) & Initial pH $\sim 5.44$ \\
\hline
\end{tabular}

\begin{tabular}{rr}
\hline T2 (Sample 2) & $6.5 \mathrm{pH}$ \\
T3 (Sample 3) & $7.5 \mathrm{pH}$ \\
T4 (Sample 4) & $8.5 \mathrm{pH}$ \\
\hline
\end{tabular}

Then each sample should be heated up to $101^{\circ} \mathrm{C}$ (little above the boiling point). After that juice samples were taken and placed in to separate graduated cylinders of $1000 \mathrm{ml}$ capacity for settling at least 2 and half hours. From the graduated cylinders, clarified juice (CJ) samples was taken and analysed for Brix, Pol, Purity, reducing sugar, calcium oxide, TSS, TDS, mud volume and turbidity. The experiment was conducted using randomized complete block design with five replicates (One block is defined as treatments done in a day).

\section{Sample analysis methods -}

Percentage of Brix was measured from the separated juice using digital brix meter. It is represented percentage of total soluble solids in given juice sample. Pol \% juice (apparent sucrose) was measured from the same juice by using Polarimeter and Purity was calculated as Pol/Brix $\times 100$. Reducing sugars were measured from cane juice using Lane \& Eynon (original) method [7]. The turbidity of the clear juice was determined according to the method of GS7-21 (2007). The concentration of calcium in clear juice were determined using EDTA method [7]. Brix\%, Pol\%, reducing sugar\%, Purity $\%$, Turbidity, TSS and TDS were calculated before and after the clarification.

\section{Statistical analysis -}

Data were analyzed using analysis of variance (ANOVA). The Duncan's Mean separation procedure was used to compare the four treatments and untreated mixed juice (UMJ) sample.

Regression analysis was carried out to model the relationship between turbidity vs $\mathrm{pH}$, mud volume vs $\mathrm{pH}$ and $\mathrm{CaO}$ vs $\mathrm{pH}$ of the juice. Scatter plots were generated to identify the pattern of the data. The linear, quadratic and cubic forms were fitted using OLS method, and the best fit form were selected based on the magnitude of adjusted $\mathrm{R}^{2}$ and the significance of the model components at $5 \%$ probability level.

SAS (Ver 9.1) and Minitab (Ver 17) software were used for the data analysis.

\section{RESULTS AND DISCUSSION}

Turbidity, reducing sugar, Brix, Pol, Purity, Mud Volume, calcium oxide and color were measured to study the individual performances of the each treatments (T1(initial $\mathrm{pH}$ ), $\mathrm{T} 2(\mathrm{pH}=6.5), \mathrm{T} 3(\mathrm{pH}=7.5), \mathrm{T} 4(\mathrm{pH}=8.5))$. Lime was added to increase the $\mathrm{pH}$ to $6.5,7.5$, and 8.5 during clarification. However, the $\mathrm{pH}$ values were slightly dropped after heating to $6.25,7.04$, and 8.30 , respectively. 


\section{International Journal of Engineering Applied Sciences and Technology, 2021 \\ Vol. 6, Issue 1, ISSN No. 2455-2143, Pages 14-20 \\ Published Online May 2021 in IJEAST (http://www.ijeast.com)}

The response of each treatment conditions to select main quality parameters are described separately as below.

Table - 2 Average Physical and Chemical characteristics data obtained from clarification test $(n=5)$

\begin{tabular}{|c|c|c|c|c|c|c|c|c|c|c|}
\hline $\begin{array}{l}\text { Treatment } \\
\text { No. }\end{array}$ & pH & $\begin{array}{c}\text { Turbidity } \\
\text { (IU) }\end{array}$ & Pol \% & Brix \% & Purity \% & $\begin{array}{c}\text { TSS } \\
(\mathrm{mg} / \mathrm{L})\end{array}$ & $\begin{array}{c}\text { TDS } \\
(\mathbf{m g} / \mathbf{L})\end{array}$ & RS \% & $\begin{array}{c}\mathrm{CaO} \\
(\mathbf{p p m})\end{array}$ & $\begin{array}{c}\text { Mud } \\
\text { Volume } \\
(\mathrm{ml})\end{array}$ \\
\hline $\begin{array}{c}\text { UMJ } \\
\text { (Untreate } \\
\text { d mixed } \\
\text { juice) }\end{array}$ & & 218.76a & $15.07 b$ & $17.56 \mathrm{~b}$ & 85.78ab & $11750 a$ & $158360 \mathrm{~b}$ & $0.399 \mathrm{c}$ & & \\
\hline T1 & $\begin{array}{c}5.44 \\
\text { (Initial } \\
\text { pH) }\end{array}$ & $153.66 \mathrm{~b}$ & $17.13 \mathrm{a}$ & $20.14 a$ & $84.98 b$ & $12140 \mathrm{a}$ & $192700 \mathrm{a}$ & $0.584 a$ & $0 \mathrm{c}$ & Od \\
\hline T2 & 6.5 & $64.42 \mathrm{c}$ & $17.08 \mathrm{a}$ & $19.44 a$ & 87.9a & 10430a & 186710a & $0.514 b$ & $2445 b$ & $60 \mathrm{c}$ \\
\hline T3 & 7.5 & $3.64 d$ & $17.27 \mathrm{a}$ & 19.66a & 87.83a & $10470 \mathrm{a}$ & 188940a & $0.559 a$ & 2715ab & $270 \mathrm{~b}$ \\
\hline T4 & 8.5 & $6.12 \mathrm{~d}$ & $17.34 a$ & $19.66 a$ & $88.19 \mathrm{a}$ & 10590a & $190970 \mathrm{a}$ & 0.540ab & 2945a & 364a \\
\hline
\end{tabular}

TSS $=$ Total Suspended Solids, TDS $=$ Total Dissolved Solids, RS $=$ Reducing Sugar

*For each clarification parameter and CJ composition, figures with the same letters are not significantly $(P>0.05)$ different.

Average physical and chemical characteristics data obtained from clarification test are shown in table 2 .

\section{Turbidity}

Turbidity value of juice samples were decreased as the increase of $\mathrm{pH}$ values from initial $\mathrm{pH} 5.44$ (T1) to $\mathrm{pH} 7.5$ (T3), but turbidity value was begun to increase again when the $\mathrm{pH}$ increases to 8.5 . Therefore $\mathrm{pH} 7.5$ shows the lowest turbidity value.

Juice turbidity mainly caused by suspended impurities. Thus, turbidity removal is considered as primary objective and therefore turbidity measurement can be used as a high degree of confidence measurement to measure the efficiency of clarification [8]. Lime was added to neutralize the juice and form insoluble lime salts such as Calcium Phosphates. Colloidal matters such as pectins, hemicelluloses, proteins and coloured compounds are absorbed by the precipitated ions and some colloids are flocculated by heat. Therefore turbidity of treated juice samples decreased compare to UMJ, due to removal of impurities. And also T1 and T2 were shown significantly high values of turbidity compared to T3 and T4. Since low liming $\mathrm{pH}$ in the process leads to limitation of reaction with existing phosphate content and reduction in catching impurities. But excess lime to $8.5 \mathrm{pH}$ gave adverse effect on turbidity. Therefore, liming to a certain $\mathrm{pH}$ is necessary to achieve lower turbidity. Among the tested treatments liming to $\mathrm{pH} 7.5$ (T3) with heating is suggested in cold liming process to achieve lower turbidity in clarified juice. Further, regression analysis revealed that the quadratic model $(\mathrm{R} 2=99.2 \%, \mathrm{p}<0.001)$ best fitted to explain the effect of $\mathrm{pH}$ on turbidity of juice (Equation 01 ). The fitted line plot and the $95 \%$ confidence Interval $(95 \% \mathrm{CI})$ for turbidity and $\mathrm{pH}$ is depicted in Fig. 1 and it revealed that the data are randomly spread about the regression line and majority of data points are within the confidence limit.

$$
\text { Turbidity }=1721-425.6 \mathrm{pH}+26.32 \mathrm{pH}^{2}
$$

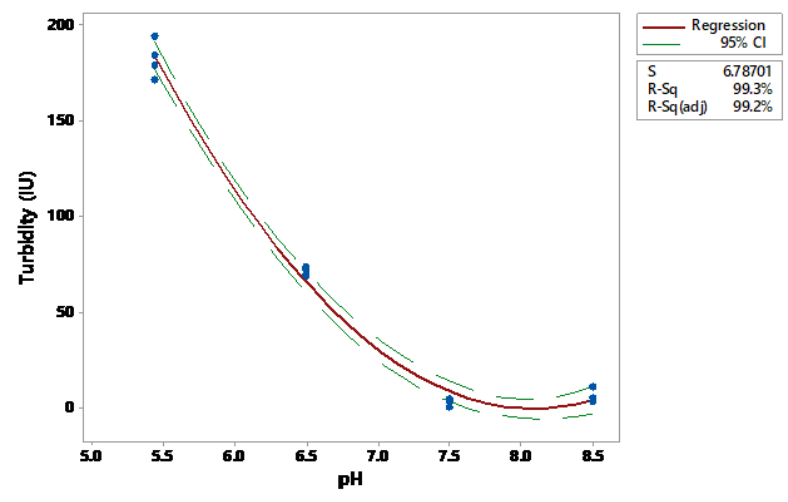

Fig. 1 Effect of $\mathrm{pH}$ on the turbidity of clarified juice.

\section{Reducing sugar}

The reducing sugar percentage was also significantly affected by the pre liming $\mathrm{pH}$ value. The $\mathrm{pH}$ adjustment of sugar cane juice via the addition of MOL is a critical step during the clarification process to avoid sucrose inversion by hydrolysis in acidic conditions $(\leq \mathrm{pH} 4)$ and alkaline degradation $(\geq \mathrm{pH}$ 8) [13]. Sucrose mostly hydrolyses to make reducing sugars, glucose and fructose, which are available in the form of fructosyl oxocarbenium cation and D-glucose at the extreme acidic and alkaline juice conditions.

According to Table 2, highest value of reducing sugar was recorded in the $\mathrm{T} 1(\mathrm{pH}=5.44)$ due to hydrolysis of available sucrose in to reducing sugars in acidic conditions. And also reducing sugar value was begun to reduce again when the $\mathrm{pH}$ rises to 8.5 (T4) due to alkaline degradation. Therefore, liming to a certain $\mathrm{pH}$ is necessary to maintain optimum level of reducing sugar in the given sugarcane juice sample.

\section{Pol/Brix/Purity}

Sucrose is most stable $\sim \mathrm{pH} \mathrm{8.3,} \mathrm{whereas} \mathrm{glucose} \mathrm{and} \mathrm{fructose}$ (invert sugars) are most stable at severe acid conditions such as $\mathrm{pH} 3-4$, thus balancing both sucrose and invert sugars at optimum level is a real challenges to sugar industries [9]. In the above paragraph, the variation in Glucose and Fructose (Reducing Sugar) was analysed at different $\mathrm{pH}$ levels, whereas 


\section{International Journal of Engineering Applied Sciences and Technology, 2021 \\ Vol. 6, Issue 1, ISSN No. 2455-2143, Pages 14-20 \\ Published Online May 2021 in IJEAST (http://www.ijeast.com)}

the variation in Sucrose (Pol \%) at different $\mathrm{pH}$ levels is analysed in this paragraph.

Since some of the dissolved non sugars removed from the mixed juice (MJ), the pol of the Clarified Juice (CJ) samples (T1, T2, T3 and T4) significantly exceeds that of the UMJ sample. And also brix value of Clear Juice (CJ) samples (T1, T2, T3 and T4) significantly exceeds that of the UMJ due to increase of dissolved ions with introducing liming. However, the ratio of pol to Brix (Purity \%) of the treatments T1 to T4 is not significantly different from that of the UMJ.

However there are no significant difference between treatments (T1 to T4), for pol \% and Brix \%, while purity of T1 significantly lower compared to other treatments.

\section{Mud Volume}

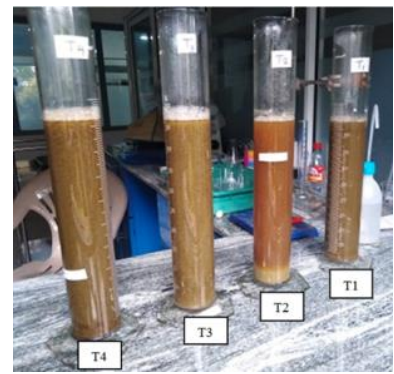

(a)

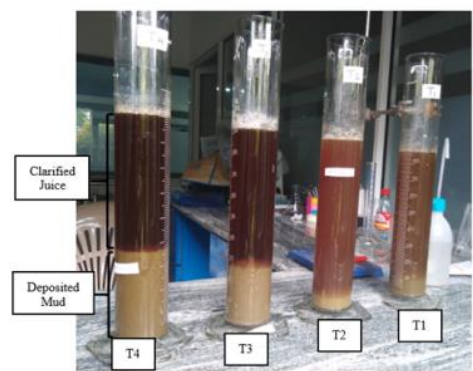

(b)
Fig. 2. (a) Before clarification (b) After Clarification

After treating with different $\mathrm{pH}$ values, Precipitation of various calcium phosphates forms are occurred in sugarcane juice samples. Equation 2 is shown the dicalcium phosphate form of precipitation. Secondary reaction takes place to form intermediate calcium phosphate phases due to the creation of unstable and insoluble dicalcium phosphate in water. Therefore the most stable compound of the calcium phosphate phases are shown in Equations 3, 4, 5 and 6 [3],[10].

$\mathrm{Ca}^{2+}{ }_{(\mathrm{aq})}+\mathrm{HPO}_{4}^{2-}{ }_{(\mathrm{aq})} \longrightarrow \mathrm{CaHPO}_{4(\mathrm{~s})}($ dicalcium phosphate)

$\mathrm{Ca}^{2+}{ }_{(\mathrm{aq})}+{ }^{2 \mathrm{H}_{2} \mathrm{PO}_{4}^{-}}{ }_{(\mathrm{aq})} \longrightarrow \mathrm{Ca}\left(\mathrm{H}_{2} \mathrm{PO}_{4}\right)_{2(\mathrm{~s})}($ monocalcium phosphate) (3)

$3 \mathrm{Ca}^{2+}{ }_{(\mathrm{aq})}+2 \mathrm{PO}_{4}^{3-}{ }_{(\mathrm{aq})} \longrightarrow \mathrm{Ca}_{3}\left(\mathrm{PO}_{4}\right)_{2}(\mathrm{~s})$ (tricalcium phosphate) (4)

$\left.2 \mathrm{CaHPO}_{4(\mathrm{aq}}\right)+2 \mathrm{Ca}_{3}\left(\mathrm{PO}_{4}\right)_{2(\mathrm{aq})} \longrightarrow \mathrm{Ca}_{8} \mathrm{H}_{2}\left(\mathrm{PO}_{4}\right)_{4(\mathrm{~s})}$ (octacalcium phosphate) (5)

$\mathrm{Ca}_{3}\left(\mathrm{PO}_{4}\right)_{2}+2 \mathrm{Ca}^{2+}+\mathrm{HPO}_{4}^{2-}+\mathrm{H}_{2} \mathrm{O} \longrightarrow \mathrm{Ca}_{5}\left(\mathrm{PO}_{4}\right)_{3} \mathrm{OH}_{(\mathrm{s})}+2 \mathrm{H}^{+}(\mathrm{aq})$

(hydroxyapatite) (6)

Type of calcium phosphate phase which is formed during clarification process is depend on the concentration of calcium and phosphate, $\mathrm{pH}$ and the nature of the particle interface [3]. Therefore settling rate and final mud volume are differed with $\mathrm{pH}$ values of the treatments. Final mud volume was increased with the increase of $\mathrm{pH}$ liming and it was highest in treatment $4(\mathrm{pH}=8.5)$. That leads to highest juice clarity.

Regression analysis revealed that the cubic model $(\mathrm{R} 2=99.4$ $\%, \mathrm{p}<0.001)$ best fitted to explain the effect of $\mathrm{pH}$ on deposited mud volume (ml) (Equation 7). The fitted line plot and the $95 \%$ confidence Interval $(95 \% \mathrm{CI})$ for mud volume and $\mathrm{pH}$ is depicted in Fig. 3 and it revealed that the data are randomly spread about the regression line and majority of data points are within the confidence limit.

Mud volume $=13805-6240 \mathrm{pH}+916.0 \mathrm{pH}^{2}-43.29 \mathrm{pH}^{3}$

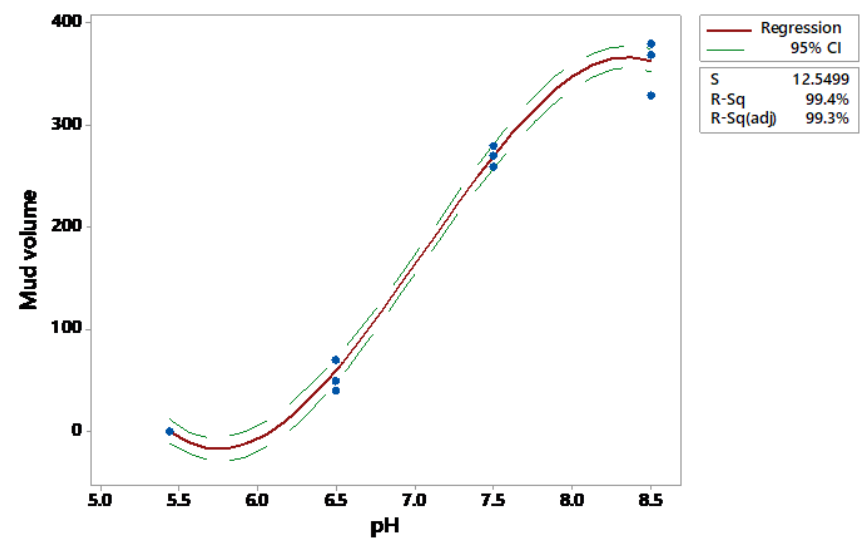

Fig. 3. Effect of $\mathrm{pH}$ on the deposited Mud volume after Clarification

\section{$\mathrm{CaO}$}

When the $\mathrm{pH}$ liming increases, the mud volume increases but it was observed that the residual concentration of calcium also increased with the $\mathrm{pH}$. Introduced $\mathrm{Ca}^{2+}$ ions in to juice samples react with $\mathrm{P}_{2} \mathrm{O}_{5}$ to form a calcium phosphate precipitation, but some amount of $\mathrm{Ca}^{2+}$ ions are remained in the clarified juice due to limited amount of natural occurring $\mathrm{P}_{2} \mathrm{O}_{5}$ in the sugarcane juice. Therefore calcium oxide content of clear juice increased with increased levels of liming $\mathrm{pH}$ according to the above Table 2 . Therefore higher calcium level in the clarified juice obtained with higher $\mathrm{pH}(\mathrm{pH} \sim 8.5)$ result in an increase in scale formation in the evaporators.

The regression analysis revealed that the cubic model $(\mathrm{R} 2=$ $93.9 \%, \mathrm{p}<0.001)$ best fitted to explain the effect of $\mathrm{pH}$ on $\mathrm{CaO}$ (ppm) of clarified juice (Equation 8). The fitted line plot and the $95 \%$ confidence Interval $(95 \% \mathrm{CI})$ for $\mathrm{CaO}$ and $\mathrm{pH}$ is depicted in Fig. 4.

$\mathrm{CaO}=-131455+53651 \mathrm{pH}-7142 \mathrm{pH}^{2}+316.5 \mathrm{pH}^{3}$ 


\section{International Journal of Engineering Applied Sciences and Technology, 2021 \\ Vol. 6, Issue 1, ISSN No. 2455-2143, Pages 14-20 \\ Published Online May 2021 in IJEAST (http://www.ijeast.com)}

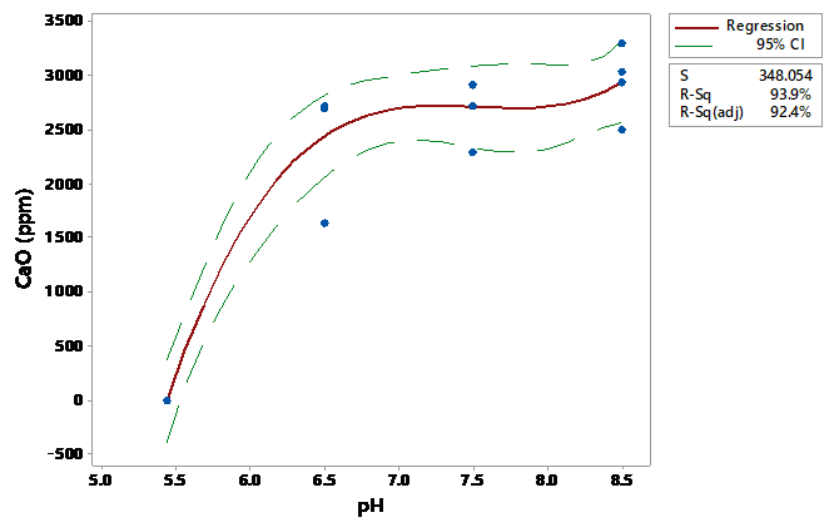

Fig. 4. Effect of $\mathrm{pH}$ on $\mathrm{CaO}$ content in clarified juice

\section{Color}

The formation of colourants produced during factory processing is mainly due to sugar degradation reactions. Reducing sugars, such as glucose and fructose, formed by the inversion of sucrose, play an important role in the formation of colour. These sugars degrade due to changes in operating conditions such as $\mathrm{pH}$ and temperature to form highly reactive intermediates, which undergo condensation and polymerisation reactions to form highly coloured polymers [11]. According to the Fig. 2, clarified juice color was darkened with the increase of $\mathrm{pH}$ liming from $\mathrm{T} 1$ to $\mathrm{T} 4$.

Colourants such as caramels and melanoidins are $\mathrm{pH}$ insensitive; therefore their colour does not change across $\mathrm{pH}$ 5.44-8.5. But flavonoids and phenolic compounds (i.e., colour precursors) are highly $\mathrm{pH}$ sensitive. Therefore, these types of compounds are lightly coloured at $\mathrm{pH} 5.44$ (lower liming $\mathrm{pH}$ ) and darken greatly at pH 8.5 (highly alkaline conditions) [11]. This is because at $\mathrm{pH} 8.5$, the ionization of these compounds is almost complete. Hence, these compounds are more highly coloured in their anionic form than in their neutral form. That's the reason behind the color variation of clarified juice which is mentioned in Fig. 2.

Main juice quality parameters and mud volume were separately analyzed to identify the individual performances of the each treatments ( $\mathrm{T} 1(5.44), \mathrm{T} 2(\mathrm{pH}=6.5), \mathrm{T} 3(\mathrm{pH}=7.5), \mathrm{T} 4$ $(\mathrm{pH}=8.5))$., However, turbidity measurement can be used as a high degree of confidence measurement to measure the efficiency of clarification since turbidity removal is the primary objective of the juice clarification process. Therefore, the variation of other key parameters with turbidity is further elaborated using the contour graphs.

\section{Effect of pH on turbidity and pol in juice}

In order to achieve high clarification efficiency, the turbidity value should be low. Thus according to table 2, the lower turbidity values are recorded at $7.5 \mathrm{pH}$ (3.64 IU) and $8.5 \mathrm{pH}$ (6.12 IU). When analyzing this lower turbidity with pol in juice parameter, pol in juice value should be a higher one. The darkest green color represents the highest pol in juice according to the contour graph mentioned in Fig. 5. By considering these two phenomena's, the most suitable region with best $\mathrm{pH}$ range is between 8.0 to 8.5 (pol \% > 17.3\%). But the $\mathrm{pH}$ range from 7 to 8.0 can also be taken in to consideration since it shows less variation in pol in juice > $17.25 \%$.

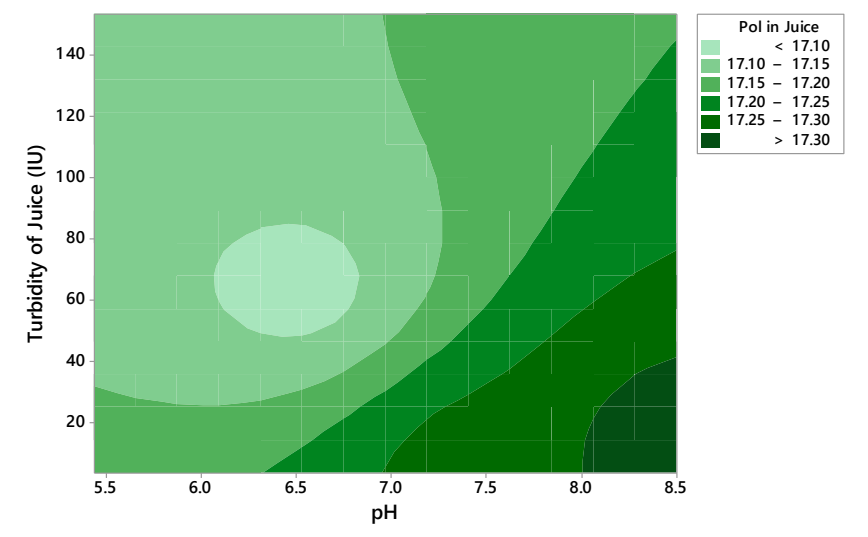

Fig. 5. Contour Plot for variation of Pol $\%$ and Turbidity with $\mathrm{pH}$ of juice

\section{Effect of pH on turbidity and reducing sugar in juice}

In order to achieve high clarification efficiency, the turbidity value should be low. According to table 2, the lower turbidity values are recorded at $7.5 \mathrm{pH}$ (3.64 IU) and $8.5 \mathrm{pH}$ (6.12 IU). When analyzing this lower turbidity with reducing sugar parameter, reducing sugar value should be low. The darkest blue color represents the lowest reducing sugar according to the contour graph mentioned in figure 6. By considering these two phenomena's, the most suitable region with best $\mathrm{pH}$ range is between 7.0 to 8.5 . Even though the $\mathrm{pH} 8.0$ to 8.5 shows much better reducing sugar value than the value showed in $\mathrm{pH}$ range of 7.0 to 8.0 , this cannot be considered since the reducing sugar started to invert at high $\mathrm{pH}$. As a conclusion, the best $\mathrm{pH}$ range is 7.0 to 8.0 by considering both Fig. 5 \& Fig. 6. 


\section{International Journal of Engineering Applied Sciences and Technology, 2021 \\ Vol. 6, Issue 1, ISSN No. 2455-2143, Pages 14-20 \\ Published Online May 2021 in IJEAST (http://www.ijeast.com)}

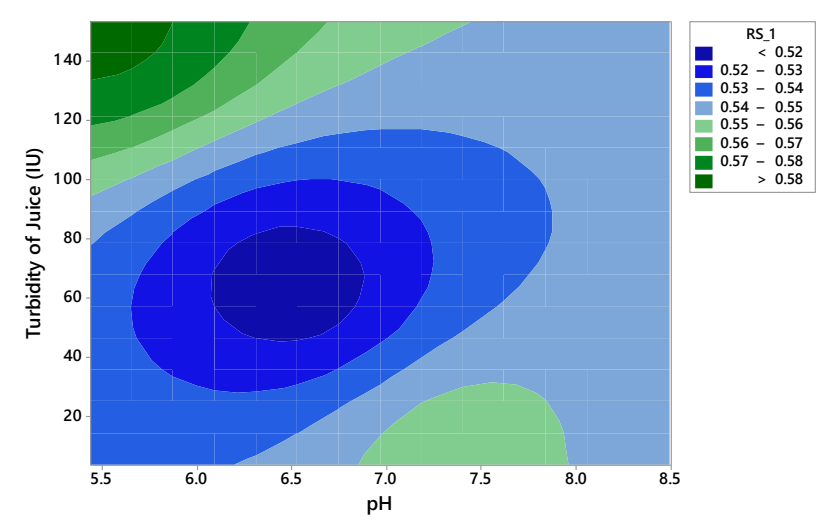

Fig. 6. Contour Plot for variation of reducing sugar $\%$ and Turbidity with $\mathrm{pH}$ of juice

\section{Effect of pH on turbidity and purity in juice}

By considering the purity of the juice, the best juice purity gives when the $\mathrm{pH}$ is between 8.0 to 8.5 , according to figure 8 . But when compare with the reducing sugar and pol in juice parameters, the optimum $\mathrm{pH}$ range is 7.0 to 8.0 with respect to Fig. $5,6 \& 7$.

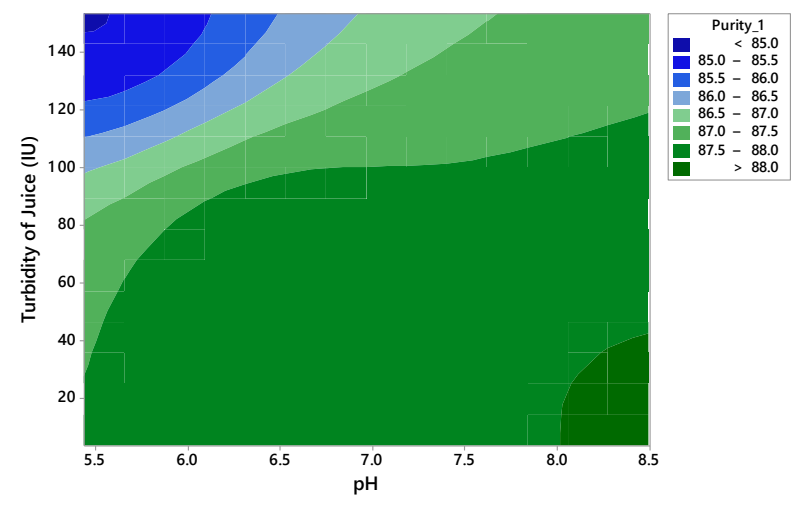

Fig. 7. Contour Plot for variation of purity $\%$ and Turbidity with $\mathrm{pH}$ of juice

Turbidity, reducing sugar, calcium oxide, Mud Volume, Brix, Pol, Purity and color were measured to study the individual performances of the each treatments ( $\mathrm{T} 1($ initial $\mathrm{pH}$ ), $\mathrm{T} 2(\mathrm{pH}=6.5), \mathrm{T} 3(\mathrm{pH}=7.5), \mathrm{T} 4(\mathrm{pH}=8.5))$. However, turbidity, reducing sugar, calcium oxide and purity are more influential in indicating the juice clarification efficiency than the rest.

Over liming to $\mathrm{pH} \sim 8.5$ can result in highly alkaline conditions and it was recorded separation of highest mud volume from the mixed juice. Although an alkaline environment can reduce sucrose losses due to inversion, but it would exacerbate scaling in the evaporators due to increase of residual $\mathrm{Ca}^{2+}$ ions in the clarified juice. As well as it promotes the formation of colourants (dark brown) and initiates to decrease reducing sugar due to the alkaline degradation of glucose and fructose. On the other hand deficit liming can cause the acidic conditions $(\mathrm{pH}=(5.44-6.5))$ and it was recorded lowest level of residual $\mathrm{Ca}^{2+}$ in the clarified juice. So it is a good sign for the retardation of scale formation in the evaporators. But under deficit liming, no clear mud separation was observed with each treatment (T1 \& T2). Furthermore, each treatments showed higher turbidity values and lower deposited mud volumes of the juice under the acidic conditions $(\mathrm{pH}=5.44 \& \mathrm{pH}=6.5)$.

\section{CONCLUSION}

Since over liming and deficit liming are not good, neutral liming to $\mathrm{pH} \sim 7.5$ should be considered for sugar clarification process. Liming to $\mathrm{pH} 7.5$ gave a lowest turbidity value. Although the precipitated mud volume at $\mathrm{pH} 7.5(270 \mathrm{ml})$ is slightly lower than the precipitated mud volume at $\mathrm{pH} 8.5$ $(370 \mathrm{ml})$, but it is significantly higher than the precipitated mud volume at $\mathrm{pH} 6.5(70 \mathrm{ml})$. In addition, the amount of residual $\mathrm{Ca}^{2+}$ ions in the clarified juice at $\mathrm{pH} 7.5$ is clearly lower than the amount of $\mathrm{Ca}^{2+}$ ions remaining in the clarified juice at $\mathrm{pH} 8.5$. Thus $7.5 \mathrm{pH}$ is selected as the best performed $\mathrm{pH}$ out of tested $\mathrm{pH}$ values.

Among tested treatments, $\mathrm{T} 3(\mathrm{pH}=7.5)$ is the best for turbidity improvement of the clarified juice while $\mathrm{T} 4(\mathrm{pH} \mathrm{8.5)}$ is second best. In contrast $\mathrm{T} 4$ is deposited significantly high mud volume than T3. It is expected to obtain high turbidity and higher mud volume with low sugar inversion at optimum $\mathrm{pH}$. Therefore the results suggest optimum $\mathrm{pH}$ range lie around $\mathrm{pH}$ 7.5 to 8.5 . Conducting similar experiment by using $\mathrm{pH}$ range around 7.0 to 8.4 at 0.2 increments is suggested to validate the optimum $\mathrm{pH}$.

\section{REFERENCE}

[1] Prati, P. and Moretti, R., (2010). Study of clarification process of sugar cane juice for consumption. Ciência e Tecnologia de Alimentos, 30(3), pp.776-783.

[2] Nour Eldien, W., H . M. Ali, E., Sohily, A. and Hamad E.A, M., 2017. Evaluation and Optimization of Hot Liming Process in Kenana Sugar Factory, White Nile State, Sudan. International Journal of Scientific and Research Publications, 7(4).

[3] C.D. Thai, C., 2013. Studies on the clarification of juice from whole sugar cane crop. Ph.D. Queensland University of Technology.

[4] Asfaw, G.(2015). Optimization of Pre-Liming and Sulphitation pHof Cane Juice onAsfaw, G., 2015. Optimization of Pre-Liming and Sulphitation pHof Cane Juice on Clarification. Degree of Master of Science. Addis Ababa University School of graduate studies. 
[5] Nocony Reece, N., 2003. Optimizing aconitate removal during clarification. Master of Science. Louisiana State University and Agricultural and Mechanical College.

[6] Doherty, W., 2011. Improved Sugar Cane Juice Clarification by Understanding Calcium OxidePhosphate-Sucrose Systems. Journal of Agricultural and Food Chemistry, 59(5), pp.1829-1836.

[7] Gupta, S.K. (2005). System of technical control for cane sugar factories in India. 2nd ed. Sugar Technologists' Association of India, pp.33-37.

[8] Mkhize, S.C.(2003). Clear juice turbidity monitoring for sugar quality. Sugar Milling Research Institute, University of Natal, Durban, South Africa.

[9] Eggleston, G. and Amorim, H.(2006). Reasons for the chemical destruction of sugars during the processing of sugarcane for raw sugar and fuel alcohol production. International Sugar Journal, 108(1289), pp.271-282.

[10] William, D. and Darryn, R., 2008. Some aspects of calcium phosphate chemistry in sugarcane clarification. In: Conference of the Australian Society of Sugar Cane Technologists. Queensland University of Technology, Brisbane, Qld: Australian Society of Sugar Cane Technologies, Australia, pp.526-535.

[11] M. T. Nguyen, D.(2013). Colour removal from sugar cane juice. Ph.D. Queensland University of Technology, Brisbane, Australia.

[12] Laksameethanasana, P., Somla, N., Janprem, S. and Phochuen, N. (2012). Clarification of sugarcane juice for syrup production. Procedia Engineering, 32, pp.141-147.

[13] Clarke, M. A. (1993). Sugars and nonsugars in sugarcane. In J. C. P. Chen \& C. C. Chou (Eds.), Chen-Chou cane sugar handbook: A manual for cane sugar manufacturers and their chemists (12th ed., pp. 21-39). New York: John Wiley and Sons. 